\title{
The Antioxidant Activity of Tobacco Smoke*
}

\author{
by \\ J. Johnson \\ Imperial Tobacco Products Limited, Montreal, Quebec, Canada \\ and
}

M. A. Nisbet

Sulphur Development Institute of Canada, Calgary, Alberta, Canada

Studies to assess the diemical, biodhemical and biological effects of tobacco smoke are often complicated by the fact that tobacco smoke is a complex mixture containing components which exert various types and degrees of activity.

The approach most widely used to determine smoke activity is usually a chemical-analytical one using classical methods of analyses, such as chromatography and spectrometry, from which a chemical profile of smoke is obtained. Although such an approach lends itself to standardization, the relevance of its actual use and interpretation is problematic, for, in view of the multitude of components in smoke, the interaction of the different substances may be expected to behave differently from that of single isolated components or purified mixtures.

A more useful and relevant approach then, would be to measure specific chemical and biochemical properties of tobacco smoke and thus obtain an "activity" profile based on the specific properties investigated.

In our laboratory we have been able to measure a number of distinct properties of smoke, e.g. interception of free radicals (polymerisation) (1), photosensitizing properties (photo-oxidation) (2), redox properties (dye-reducing, ascorbate oxidation) $(3,4)$. In addition other properties such as alkylating (5) and metal-binding (6) properties have been reported.

This paper describes yet another property of tobacco smoke, its antioxidant activity. Our primary concern was to find out whether or not smoke initiates or promates the formation of radical peroxides which would in turn lead to lipid peroxidation. Utilizing a system which involves the coupled oxidation of $\beta$-carotene and linoleic acid, and which serves as an assay for antioxidants, it was found that smoke did not contribute to the oxidative destruction of $\beta$-carotene, but rather behaved as an antioxidant. Using a slightly modified version of the procedure described by Miller (7), we have investigated the antioxidant action of tobacco smoke and compared it with a number of known antioxidants.

\footnotetext{
- Rectired for publication: 14th January, 1974.
}

\section{MATERIALS AND METHODS}

The method used was essentially the same as that described by Miller (7). Pure linoleic acid (more than $99 \%$ pure) was obtained from Serdary Research Laboratories Inc. (London, Ontario, Canada). $\beta$-carotene and Tween 40 were purchased from Canlab. (Montreal, Que., Canada). Readings were taken on a Unicam SP 1800 spectrophotometer.

A dilute oxygenated emulsion was prepared as follows: $2 \mathrm{mg}$ of crystalline $\beta$-carotene was dissolved in $10 \mathrm{ml}$ redistilled dhloroform. $2.0 \mathrm{ml}$ of this solution was pipetted into a round-bottomed flask which contained $20 \mu \mathrm{l}$ linoleic acid and $400 \mathrm{mg}$ Tween 40 . The chloroform was removed from the mixture by evaporation under vacuum at $37^{\circ} \mathrm{C}$ for $x$ hour, using a rotary evaporator fitted with a water aspirator. To the red viscous material that resulted, was added $100 \mathrm{ml}$ of oxygenated distilled water (prepared by bubbling pure oxygen through distilled water for 0.5 hours) with vigorous stirring.

A $10 \mathrm{ml}$ aliquot of the aqueous emulsion was placed into each of a series of test tubes which contained $0.2 \mathrm{ml}$ of ethanolic antioxidant solution. The control consisted of $0.2 \mathrm{ml}$ redistilled ethanol. A zero reading at $470 \mathrm{~nm}$ was taken on the reaction mixture inmediately after addition of the emulsion to the antioxidant solution. The tubes were then stoppered and placed in a water bath at $50^{\circ} \mathrm{C}$ for $0.5 \mathrm{~h}$ and optical density measured. Tests were carried out in duplicate or triplicate.

Cigarettes and cigars were smoked to a standard regime of one $35 \mathrm{ml}$ puff of 2-second duration per minute to butt lengths of $23 \mathrm{~mm}$ and $50 \mathrm{~mm}$ respectively. Pipes were smoked on a specially constructed machine drawing a $35 \mathrm{ml}$ puff of 2-second duration every to seconds. Total particulate matter (TPM) was collected on weighed Cambridge filter pads for tests on unfractionated smoke. Pads were dried in desiccators for 12 hours at $4^{\circ} \mathrm{C}$. Antioxidant solutions of TPM $(0.025 \mathrm{mg} / \mathrm{ml})$ were prepared by macerating filter pads in a mortar with the appropriate volume of ethanol and collecting the filtrate through glass wool. Sufficient cigarettes, cigars and 
pipe tobacco were smoked to give at least $20 \mathrm{mg}$ TPM. Smoke fractions were prepared by the method of Swain et al. (8). For this fractionation, the condensate from 60 cigarettes was collected by electrostatic precipitation. The final fractions were taken to complete dryness, and appropriate volumes of ethanol added to give final concentrations of $0.1 \mathrm{mg} / \mathrm{ml}$. Appropriate controls were designed in each case.

Tests on vapour phase were carried out by introducing into a hermetically sealed bag made of laminated plastic, different proportions of $\mathrm{N}$ and vapour phase. To ensure adequate mixing of the gases, glass beads were placed in the bag and the contents shaken vigorously. For the assay, 1o $\mathrm{ml}$ of the gaseous mixture was extracted from the bag by means of a gas-tight syringe fitted with a long stainless steel needle, and bubbled slowly into the emulsions of $\beta$-carotene contained in test tubes tightly stoppered with rubber septa. Test on pure vapour phase components were achieved by substituting these components for smoke vapour in concentrations similar to that found in $35 \mathrm{ml}$ (I puff) of smoke (9). A control was derived by using $10 \mathrm{ml}$ of nitrogen.

Differences in the antioxidant activity of smokes from the various sources, were isolated by application of the appropriate statistical test. Summary statistics for the control with 15 observations, showed a coefficient of variation of $3.1 \%$. The method was less precise with tobacco samples with coefficients of variation ranging from $9.6-21.4 \%$. The results are quoted as sample means \pm standard error of mean (S.E.M.) at $95 \%$ confidence intervals.

\section{RESULTS AND DISCUSSION}

The primary purpose of this study was to find out to what extent smoke was a generator of free radicals which might in turn initiate reactions leading to lipid peroxidation. The method used to examine this effect is based on the destruction of $\beta$-carotene in the coupled oxidation of $\beta$-carotene and linoleic acid using an aqueous emulsified system. The oxidation and hence destruction of $\beta$-carotene is accompanied by a decrease in its optical density at $470 \mathrm{~nm}$ and in this system bears a linear relationship with time over a period of at least 30 minutes as shown in Fig. 1 .

In the presence of antioxidants, carotene oxidation is blocked, and thus this method can be conveniently used to assess and rank antioxidants. Table I shows antioxidant response values for a number of standard antioxidants. Units of antioxidant activity, based on oxidation rates, were derived by the difference in optical density between o time and 30 minutes divided by time. To facilitate comparisons the results are further expressed as "percent efficiency" with the control (with no antioxidant) arbitrarily given $0 \%$ and BHT* $100 \%$. As can be seen, 1,2-dihydroxy-2,2,4trimethylquinoline was the most efficient, $3,3^{\prime}$-dilauryl-

BHT $=$ butylated hydroxytoluene.
Figure 1. Oxidation of $\beta$-carotene.

Linearity of $\beta$-carotene oxidation with optical density. Each point represents a mean of 4 determinations. The standard error of estimate of the curve was 0.0109 . Details of sample preparation and experimental conditions are given under "Materials and Methods".

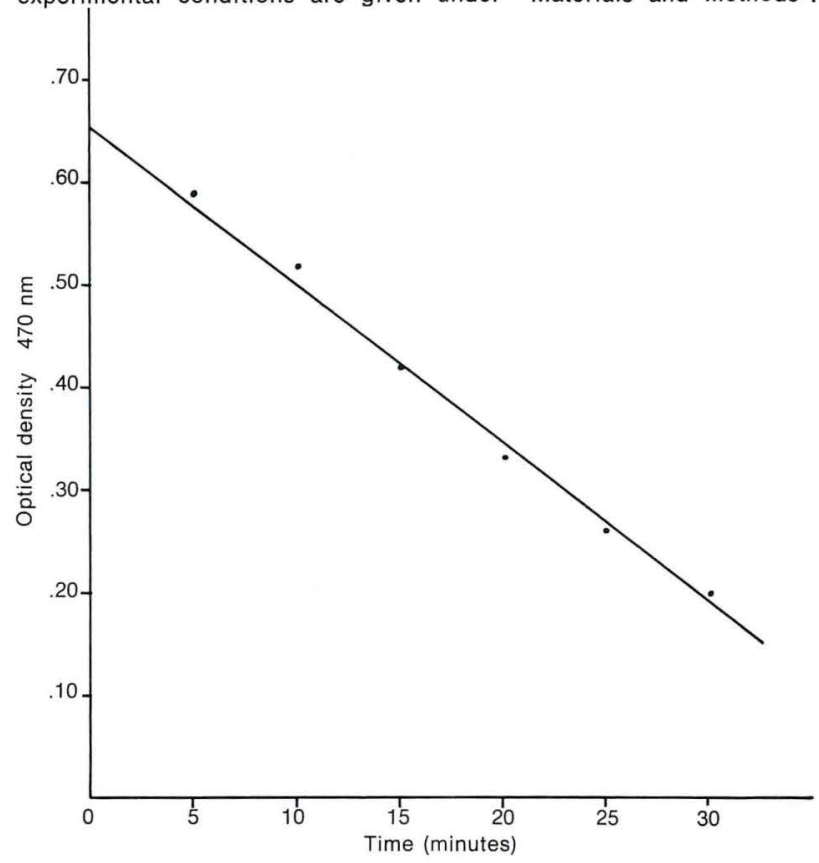

thiodipropionate the least, while ascorbic acid has an oxidation rate more rapid than the control leading to a negative antioxidant response value. Marco explains this as a pro-oxidation process and attributes it to a $\mathrm{pH}$ effect (10). According to his theory, while $\mathrm{pH}$ should not affect a purely radical system, it could affect the availability of the antioxidant for the carotene/linoleic acid globule by affecting water solubility through salt formation, thus making the chemical less available to the emulsified carotene/linoleic acid globule. The salts in a buffer system tend to alter the partitioning of antioxidant and the carotene/linoleic acid globule. To eliminate this factor, distilled water was selected for antioxidant evaluations and therefore some compounds might be expected to behave as pro-oxidants under these conditions.

Table 1. Antioxidant evaluations of pure antioxidant compounds.

\begin{tabular}{l|c|c}
\hline \multicolumn{1}{c|}{ Antioxidant } & \multicolumn{2}{c}{$\begin{array}{c}\text { Antioxidant response } \\
\text { values }\end{array}$} \\
& $\begin{array}{c}\text { Oxidation } \\
\text { rate }\end{array}$ & $\%$ Efficiency \\
\hline 1,2-dihydroxy-2,2,4-trimethyl- & 6.7 & 114.3 \\
$\quad$ quinoline (Santoquin) & 8.2 & 100 \\
Butylated hydroxytoluene (BHT) & 10.2 & 81 \\
Butylated hydroxyanisole (BHA) & 13.4 & 50.5 \\
Propyl-gallate & 18.4 & 0.3 \\
3,3'-Thiodipropionic acid & 18.7 & 0 \\
3,3'-Dilaurylthiodipropionate & 19.8 & -10.5 \\
Ascorbic acid & 18.7 & 0 \\
Control &
\end{tabular}

Amount of antioxidant in each reaction tube was $1.6 \mu \mathrm{g}$. Oxidation rate equals change in optical density per unit time. $\%$ Efficiency is based on $\mathrm{BHT}=100 \%$ and Control $=0 \%$ by definition. Details of experimental conditions are given under "Materials and Methods". 
Figure 2. Rolatlve efficlencles in antloxidant actlvity of imoke and BHT (butylated hydroxytoluene).

Antloxidant activities of TPM from flue-cured tobacco and BHT at different levels of concentration. The antloxidant activity of BHT at a concentration of $1.6 \mu \rho$ was arbitrarily given $100 \%$ efficiency.

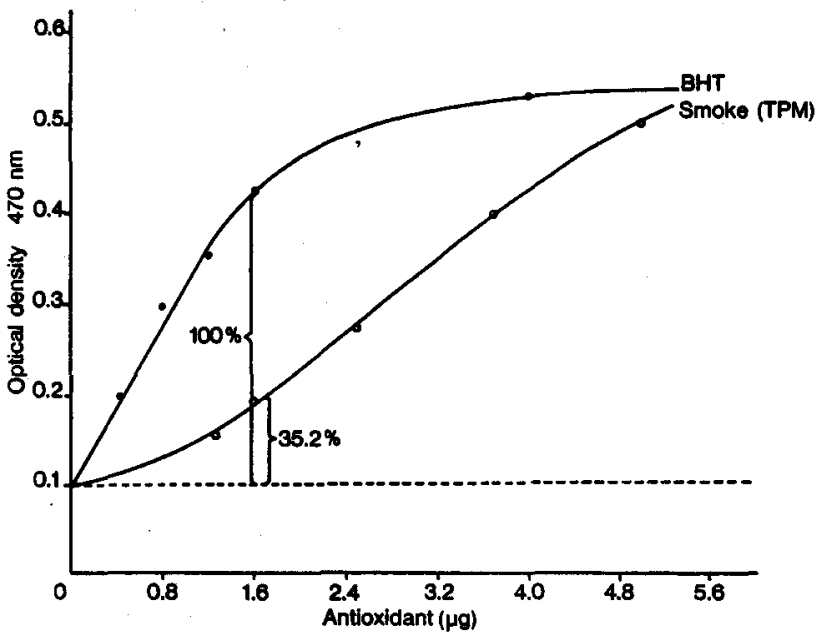

Since the amount of antioxidant affects the oxidation rate, comparisons were carried out on an equivalent weight basis at $1.6 \mu \mathrm{g}$. Fig. 2 shows the relationship between the oxidation rates and concentration for a standard antioxidant as well as TPM from flue-cured tobacco. Maximum activity (in the linear range) for BHT was found to be at $1.6 \mu \mathrm{g}$, whereas for TPM it was at $5.0 \mu \mathrm{g}$. In order therefore to relate the antioxidant activity of TPM to BHT, comparisons were carried out at $1.6 \mu \mathrm{g}$. As can be seen, at this level TPM from flue-cured tobacco was only $35.2 \%$ as efficient as BHT. For purposes of comparing the antioxidant activities of TPM from different tobaccos, a concentration of $5 \mu \mathrm{g}$ was more desirable. This comparison is shown in Table 2. Comparisons were made between the same kinds of tobacco in the cut and ground forms as well as with pure powdered cellulose in cigarette form. Grinding tobacco permits comparisons to be made between tobaccos of which there is insufficient material to manufacture cigarettes in the conventional manner.

Table 2. Antloxidant response of different tobacco smoke condensates.

\begin{tabular}{|c|c|c|c|}
\hline Sample & Form & Description & $\begin{array}{l}\text { Oxidation } \\
\text { rate }\end{array}$ \\
\hline Air (burley) & Cut & $100 \%$ lamina & 5.5 \\
\hline Flue & Cut & $100 \%$ lamina & 5.9 \\
\hline Perique & Granulated & $100 \%$ lamina & 7.5 \\
\hline Cigar & Shattered & $100 \%$ lamina & 8.2 \\
\hline Flue & Granulated & $100 \%$ lamina & 9.3 \\
\hline Stem & Cut & $100 \%$ stem & 10.8 \\
\hline Sheet & Cut & $100 \%$ sheet & 10.9 \\
\hline $\begin{array}{l}\text { Pipe (flue } \\
\text { \& burley) }\end{array}$ & Cut & Stem \& lamina & 15.7 \\
\hline Cellulose & Powder & $100 \%$ & 18.7 \\
\hline Control & & - & 18.7 \\
\hline
\end{tabular}

Each value represents a mean of 8 determinations with a pooled S.E.M. (standard error of mean) of \pm 0.013 . Samples were tested at concentrations of $5 \mu \mathrm{g}$ each.
The granulation technique used, and the manner in which cigarettes were made from the ground tobacco, were the same as described by Nisbet et al. (1). It has been shown that TPM yields from cigarettes made in this fashion are comparable to that of cigarettes made in the conventional manner (1).

No statistical differences were seen between air-cured, flue-cured cut and perique tobaccos which had the lowest rates and therefore the highest antioxidant activities. Pipe tobacco had the highest rate, while cigar, flue-cured ground, stem and sheet tobaccos had intermediate values. Cigars, however, differed statistically from flue-cured ground, stem and sheet tobaccos. Cigarettes made of cellulose had no activity proving that the antioxidant activity is a distinct property of the non-cellulosic components of tobacco.

It is interesting to note the difference in oxidation rates between the flue-cured cut and ground forms. This would indicate that the physical form of the tobacco has an effect on its antioxidant activity. The fact that pipe tobacco had the lowest activity could be interpreted as the smoking vehicle having an effect on the production of antioxidant. Another interesting observation is that similar differences were found by Nisbet et al. in their study on the photosensitized oxidation of tobacco smoke (2).

Fractionation of the total condensate to yield various smoke fractions was performed and each fraction tested for its antioxidant activity. As shown in Table 3 the neutral and water-insoluble acid fractions had the highest activities with the neutral fraction having an even greater activity than the whole smoke. Shown also are the relative amounts of each fraction on a percent weight basis as it is contained in whole smoke (1I) and the relative contribution of antioxidant activity by each fraction based on these amounts. Noticeable is the fact that the neutral fraction with the highest activity contributes only $23 \%$ to the antioxidant activity of the total smoke since it amounts to only $17 \%$ by weight of whole smoke. Similarly, the waterinsoluble acid fraction with a high activity of 0.87 units contributes only $4.4 \%$. On the other hand, the watersoluble acids with a low activity of 0.54 units, because it constitutes as much as $36 \%$ by weight of whole

Table 3. Antloxidant activity of smoke fractions derived from condensates from flue-cured tobacco.

\begin{tabular}{l|c|c|c}
\hline Fraction & $\begin{array}{c}\text { Activity } \\
\text { per } \mu g\end{array}$ & $\begin{array}{c}\% \text { by weight } \\
\text { of fractions } \\
\text { in whole } \\
\text { smoke (11) }\end{array}$ & $\begin{array}{l}\text { Relative \% con- } \\
\text { tribution of anti- } \\
\text { oxidant activity } \\
\text { by each fraction }\end{array}$ \\
\hline Total & 0.97 & & \\
Neutrals & 1.36 & 17 & 23.1 \\
Water-insoluble acids & 0.87 & 5 & 4.4 \\
Water-insoluble bases & 0.56 & 4 & 1.3 \\
Water-soluble acids & 0.54 & 36 & 19.4 \\
Water-soluble bases & 0.49 & 2.4 & 2 \\
\hline
\end{tabular}

Activity was obtained from the inverse of the oxidation rate for purposes of clarity. The results were obtained from three independent experiments. 
smoke, contribute $19.4 \%$ to the antioxidant activity. The water-insoluble acid fraction contains phenols, high molecular weight acids and pigments. Further fractionation of this group of compounds into phenols and straight chain acids revealed that $77 \%$ of antioxidant activity resided in the phenolic fraction. This is not surprising since in this fraction, compounds resembling BHT and other standard antioxidants are present. No attempt was made to further purify and identify individual compounds in the neutral fraction, but here unsaturated compounds such as conjugated dienes and other unsaturated hydrocarbons are known to be present and these compounds with active hydrogens would be expected to participate in free-radical reactions, which as will be discussed later, might be involved in mechanisms leading to antioxidation.

Vapour phase was found to be strongly antioxidant, but a high coefficient of variation ranging from $3.6-28 \%$ was encountered, so that it was not feasible to compare the vapour phase of different tobaccos by this method. The variation of vapour phase with oxidation rate however, is shown in Fig. 3.

Several pure compounds known to occur in vapour phase were tested for their antioxidant activities over a range of concentrations similar to that encountered in vapour phase. As shown in Table $4, \mathrm{HCN}$ exhibited the highest antioxidant activity (even more so than total vapour phase) accounting for $92 \%$ of total inhibition. Isoprene, one of the major unsaturated compounds, surprisingly had little effect even at a concentration several times that found in smoke vapour. A negative synergistic effect is seen where $\mathrm{HCN}$ loses its efficiency when combined with isoprene to give an activity similar to that of the total vapour phase. This synergism probably accounts for the fact that pure $\mathrm{HCN}$ by itself had a higher activity than total vapour phase.

From a mechanistic point of view, it is generally accepted that carotene decolorization in the presence of fatty acids occurs by a free-radical mechanism. Our observations regarding the behavior of smoke as an antioxidant in the coupled oxidation of linoleic acid and $\dot{\beta}$-carotene, can be explained as an inhibition of the auto-oxidative process whereby $\beta$-carotene is oxidized through the reaction of free peroxy radicals. According to the established theory of lipid oxidation, hydroperoxides are the initial and predominant products and act as catalysts for a chain reaction by supplying radicals. Molecular oxygen is involved in the formation of the first lipid peroxides. The latter originate by the abstraction of the allylic hydrogen. The carotene then acts as an acceptor of peroxidic oxygen.
Figure 3. Antloxidant actlvity of vapour phase of fluecured tobacco.

Effect of vapour phase of flue-cured tobacco on $\beta$-carotene oxldation. Each value is the mean of 9 independent experiments.

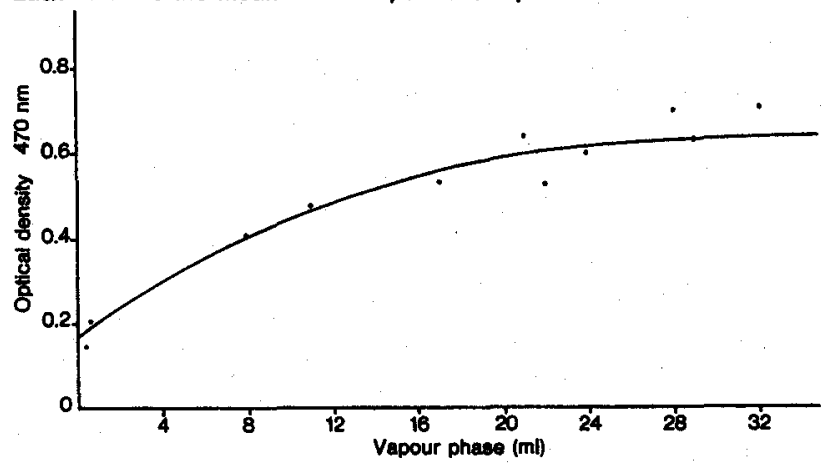

Hydroxy- and dioxocarotene, the oxidation products of the $\beta$-carotene, are colorless substances and are responsible for the decolorization (and hence the decrease in optical density, see Fig. I) which occurs in the $\beta$-carotene/linoleic acid emulsified system.

Table 4. Antloxidant actlvity of vapour phase and some pure vapour phase components.

\begin{tabular}{lc|c|c}
\hline \multicolumn{1}{c|}{ Sample } & Amount & $\begin{array}{c}\text { Oxidation } \\
\text { rate }\end{array}$ & $\%$ Efficiency \\
\hline Total vapour phase & $10 \mathrm{ml}$ & 6.0 & 65.7 \\
HCN & $0.6 \mu \mathrm{g}$ & 1.3 & 92.6 \\
Isoprene & $50 \mu \mathrm{g}$ & 14.7 & 16.0 \\
Acrolein & $500 \mu \mathrm{g}$ & 16.8 & 4.0 \\
NO & $0.4 \mathrm{ml}$ & 17.0 & 2.9 \\
CO & $0.2 \mathrm{ml}$ & 17.0 & 2.9 \\
$\mathrm{~N}$ (control) & $10 \mathrm{ml}$ & 17.5 & 0 \\
\hline HCN + isoprene & $0.6+50 \mu \mathrm{g}$ & 6.7 & 61.7 \\
\hline
\end{tabular}

Detals of experimental conditions are given under "Materials and Methods".

$\%$ Efticiency $=\frac{\text { Rate of control }- \text { Rate of sample }}{\text { Rate of control }} \times 100$.

Antioxidants may inhibit the production of the freeradical initiators or they may decrease the efficiency of the chain reaction ([b] and [c] below). In the latter event they act as radical scavengers by lowering the concentration of the reactive free-radical intermediates.

The types of reactions or processes in which free radicals participate are considered to fall into five categories (12):
(a) Atom or group transfer,
(b) Addition and substitution,
(c) $\beta$-scission,
(d) Electron transfer,
(e) Re-arrangement.

Of these five types reactions (a) and (b) are the most common.

Linoleic acid $\stackrel{\mathrm{O}_{2} \text { addition }}{\longrightarrow}$ linoleic hydroperoxide $\stackrel{\mathrm{H} \text { abstraction }}{\longrightarrow} \longrightarrow$ free peroxy radicals $\ldots \ldots \ldots$
$4,4^{\prime}$-Hydroxycarotene + free peroxy radicals $\longrightarrow$


In the inhibition of lipid peroxidation by an antioxidant it is generally suggested that the mechanism proceeds by radical destruction rather than by inhibition of the initiating reaction and involves mechanism (a), i. e. atom transfer.

The effectiveness of an antioxidant $\mathrm{AH}_{2}$ is dependent on the newly formed radicals being inactive in chain propagation or being destroyed by side reactions.

$$
\begin{array}{ll}
\mathrm{R} . \mathrm{OO}^{\circ}+\mathrm{AH}_{2} \longrightarrow & \mathrm{R}-\mathrm{OOH}+\mathrm{AH}^{\circ} \\
2 \mathrm{AH}^{\circ} & \mathrm{AH}_{2}+\mathrm{A} \\
\mathrm{ROO}^{\circ}+\mathrm{AH}^{\circ} \longrightarrow & \mathrm{ROOH}+\mathrm{A}
\end{array}
$$

In smoke, compounds with active hydrogens, such as the unsaturated compounds, amines, phenols, conjugated dienes, could be expected to participate in atom transfer reactions outlined above. In the case of particulate matter, the antioxidant activity is clearly defined in the neutral and water-insoluble fractions, but with vapour phase, the situation seems more complicated, although it was found that $\mathrm{HCN}$ accounted for considerable antioxidant activity.

Free radicals occur as intermediates in many biodemical processes and can be detected in most animal and plant cells. They are involved in both normal biochemical processes (all redox reactions involve radical intermediates) as well as in abnormal processes (peroxidation of unsaturated lipids) $(12,13)$. In addition, formation of hydroperoxides, as a result of lipid oxidation, leads to secondary products such as aldehydes, ketones, acids, etc. Interactions of such products with proteins contribute to the destruction of their natural biological activities and hence cause toxicity to biological systems (14).

The possibility that aging is caused by free radicals has also been proposed $(12,13)$. Free radicals such as $\mathrm{HO}$ and $\mathrm{HO}_{2}$ can be involved in the various oxidative reactions that can possibly cause some of the phenomena of aging (deterioration of membranes, collagen and elastin). A large variety of substances occur naturally in animal tissues which function as antioxidants (e.g. Vitamin $E$, Coenzyme Q). On the other hand, ingestion of antioxidants (BHA, BHT) which are added to foodstuffs as a preservative and stabilizer of fats and oils, serve as well to assist the body in destroying or tying up free radicals. It has also been shown that the antioxidants BHA, BHT and Ethoxquin inhibit the carcinogenicity of benzo(a)pyrene and 7,12-dimethylbenzanthracene in the mouse (15). It is hereby suggested that because of its antioxidant property, smoke is not involved in those reactions leading to lipid peroxidation or other oxidative reactions which could contribute to aging and other deleterious phenomena.

\section{SUMMARY}

Cigarette smoke has been shown to contain free radicals in both the vapour and particulate phases. The present investigation was undertaken to find out whether these radicals could initiate or promote the formation of radical peroxides which might in turn lead to lipid peroxidation. To investigate this, a system involving the coupled oxidation of $\beta$-carotene and linoleic acid was utilized. In this coupled reaction, $\beta$-carotene is destroyed through oxidation by free peroxy radicals. The system can therefore be used as a convenient detector of auto-oxidative medhanisms in which peroxide radicals participate, as well as provide an assay for antioxidants, since in their presence oxidative destruction of $\beta$-carotene is blocked.

Our results show that smoke did not contribute to the oxidative destruction of $\beta$-carotene but rather behaved as an antioxidant. Both smoke vapour and particulate matter were found to be highly antioxidant. A number of pure vapour phase components were tested and the bulk of antioxidant activity was found to be due to HCN. Smoke condensates from different tobacco types were compared and differentiated according to their relative efficiencies of antioxidant activities. For comparison, units of antioxidant activity were expressed as rate of change of optical density with time. The highest antioxidant activities were obtained with air-, flue-cured (cut) and perique tobaccos. Pipe tobacco had the least activity while cigar and flue-cured (granulated), stem and sheet tobaccos had intermediate values. Tests done on smoke fractions derived from the fractionation of total condensate revealed that antioxidant activity resided largely in the neutral and water-insoluble acid fractions with virtually no activity in the basic fractions.

The mode of antioxidant action of tobacco smoke is discussed in terms of free-radical medhanisms.

\section{ZUSAMMENFASSUNG}

Es ist berichtet worden, daß sowohl in der Dampf- wie auch in der Partikelphase von Cigarettenrauch freie Radikale enthalten sind. Die vorliegende Arbeit wurde durchgeführt, um zu untersuchen, ob diese Radikale die Bildung von Peroxid-Radikalen auslösen oder fördern könnten, die ihrerseits zu Lipoid-Peroxiden führen könnten. $Z u$ diesem $Z$ weck wurde ein System benutzt, das auf gekoppelter Oxydation von $\beta$-Karotin und Linolsäure basiert. Bei dieser Reaktion wird $\beta$-Karotin oxidativ durch freie Peroxid-Radikale zerstört. Dieses Prinzip kann daher sowohl als bequemer Indikator für Autoxydationsvorgänge dienen, an denen Peroxid-Radikale beteiligt sind, als auch zum Nachweis von Antioxidantien benutzt werden, $\mathrm{da}$ in deren Gegenwart die oxidative Zerstörung von $\beta$-Karotin blockiert wird. Unsere Ergebnisse zeigen, daß Rauch an der oxidativen Zerstörung von $\beta$-Karotin nicht teilnimmt und sich eher wie ein Antioxidans verhält. Sowohl die Dampfphase wie auch die Partikelphase des Rauches erwiesen sich in starkem Maße als Antioxidantien. Die Untersuchung einer Reihe reiner Inhaltsstoffe der Dampfphase ließ erkennen, daß die antioxidative Aktivität zum größten Teil auf HCN beruht. Die Rauchkondensate verschiedener Tabakarten wurden verglichen und entsprechend 
dem relativen Wirkungsgrad der antioxidativen Aktivität differenziert. Zum Vergleich wurde die Einheit „antioxidative Aktivität" ausgedrückt als Veränderung der optischen Dichte (O.D.) pro Zeiteinheit. Die stärkste Aktivität zeigten "air-cured"-Tabak, "flue-cured"Schnittabak und Perique-Tabak. Pfeifentabak hatte die geringste Aktivität, während Zigarrentabak, "Aluecured"-Tabakgranulat, Rippen- und Folientabake mittlere Werte aufwiesen. Untersuchungen an Fraktionen des Gesamtkondensates ließen erkennen, daß die antioxidative Aktivität vorwiegend in den neutralen und wasserunlöslichen sauren Fraktionen enthalten ist und daß die basischen Fraktionen diese Eigenschaft praktisch nidht haben.

Die Wirkungsweise der antioxidativen Aktivität des Tabakrauches wird als Reaktion freier Radikale diskutiert:

\section{RESUME}

Il a été démontré que la fumée de cigarette contient des radicaux libres dans la phase vapeur et dans la phase particulaire. L'étude présente est destinée à examiner si ces radicaux peuvent initier ou promouvoir la formation de radicaux peroxydes, pouvant à leur tour initier la peroxydation des lipides. On a utilisé à cette fin un système d'oxydation couplée du bêta-carotène et de l'acide linoléique. Dans cette réaction couplée, les radicaux libres peroxy détruisent le bêta-carotène par oxydation. Ce système peut donc être utilisé facilement comme détecteur des mécanismes auto-oxydants auxquels des radicaux peroxydes prennent part, ainsi que comme essai d'antioxydants, puisqu'en leur présence la destruction oxydative du bêta-carotène est inhibée.

Nos résultats montrent que la fumée ne contribue pas à la destruction oxydative du carotène, mais se comporte plutôt comme un antioxydant. La vapeur et la matière particulaire ont toutes deux une action antioxydante importante. On a examiné un nombre important de composants purs de la phase vapeur, et le gros de l'activité antioxydante est dû à l'acide cyanhydrique. Les condensats de fumée de différents types de tabac ont été comparés et classés suivant leur activité antioxydante relative. Pour permettre la comparajson, les unités d'activité antioxydante ont été exprimées en fonction du changement de la densité optique (O.D.) par rapport au temps. Les activités antioxydantes les plus importantes ont été obtenues avec des tabacs "air-cured", «flue-cured" (coupés) et perique. Les tabacs à pipe ont montré le moins d'activité, tandis que les tabacs à cigares, les tabacs «flue-cured" (granulés), less tabacs de côtes et reconstitués en feuille ont montré des valeurs intermédiaires. Certains tests faits sur des fractions de fumée dérivées du fractionnement du condensat total ont révélé que l'activité antioxydante est principalement le fait des fractions neutres et acides insolubles dans l'eau, et pratiquement nulle dans les fractions basiques.

Le mode d'activité antioxydante de la fumée de tabac est discuté en termes de radicaux libres.

\section{REFERENCES}

1. Bilimoria, M. H., J. Johnson, M. A. Nisbet, S. Schmeller, and K. K. Georgieff: Beitr. Tabakforsch. 7 (1973) $x 58$.

2. Nisbet, M. A., J. Johnson, and S. Schmeller: Tob. Sci. XVI (1972) 13.

3. Benedict, R. C., L. Lakritz, G. D. Strange, and R. L. Stedman: Chem. and Ind., No. 24, 800, June I.97o.

4. Bilimoria, M. H., and M. A. Nisbet: Beitr. Tabakforsch. $6(197 x) 27$.

5. Stedman, R. L., and R. L. Miller: Chem. and Ind., 15 April, 618, 1967.

6. Michael, L. W., G. E. Mendeen, and H. G. Petering: Environ. Sci. Tech. 5 (1971) 249.

7. Miller, H. E.: J. Amer. Oil Chem. Soc. 48 (2) (1971) 91.

8. Swain, A. P., J. E. Cooper, and R. L. Stedman: Cancer Res. 29 (1969) 579.

9. Elmenhorst, H., and C. Schultz: Beitr. Tabakforsch. 4 (1968) go.

10. Marco, Gino J.: J. Amer. Oil Chem. Soc. 45 (1968) 594.

11. Nisbet, M. A., and S. Sdumeller: Unpublished.

12. Pryor, William A.: Chem. \& Eng. News, 7 June, $58, x 97 x$.

13. Sanders, Howard J.: Chem. \& Eng. News, 24 July, $13,1972$.

14. Gamage, P. T., and S. Matsushita: Agr. Biol. Chem. 37 (1973) 1.

15. Wattenberg, Lee W.: J. Nat. Cancer Inst. $4^{8}$ (1972) 1425.

The authors' address:

Imperial Tobacco Products Ltd.,

Research and Development; 3810 St. Antoine Street, P.O. Box 6500, Montreal 207, Quebec, Canada. 